\title{
Ideja permanentnega izobraževanja pri J. A. Komenskem v delu Pampaedia
}

\section{(Vsesplošno poučevanje)}

\author{
Tadej Vidmar
}

Pampaedia tudi danes, po treh stoletjih, predstavlja temeljno delo teorije permanentnega izobraževanja, saj skorajda ni stvari, ki je ne bi mogli, ko odstranimo literarno hotenje (dela Komenskega niso zgolj puste razprave), aktualizirati in prenesti v naš čas. Večino stvari v zvezi s sodobno teorijo permanentnega izobraževanja je Komenski opazil, predvidel ali zahteval že $v$ 17. stoletju.

Jan Amos Komenski se je rodil leta 1592 v Uherskem Brodu na Moravskem. Solal se je na latinski šoli v Prerovu, nato pa na akademiji v Herbornu v Nemčiji. Teologijo je študiral na protestantski univerzi $v$ Heildelbergu. Bil je pripadnik protestantske (husitske) ločine Edinosti čeških bratov in dolgo eden izmed njenih škofov in voditeljev. Vse življenje si je prizadeval za osvoboditev svoje domovine izpod Habsburžanov in za versko skupnost. Njegova življenjska pot je bila, lahko bi rekli, precej tragična, saj je večino svojega življenja preživel v izgnanstvu, seleč se od enega dobrotnika k drugemu. Dvakrat so mu zaplenili in požgali premoženje, predvsem knjižnico z mnogimi še neizdelanimi rokopisi (nazadnje leta $1656 \mathrm{v}$ poljskem Lešnu). Tudi zasebno ni imel sreče, saj je doživel smrt dveh žena, šele tretja ga je preživela.

Komenski je bil velik idealist in optimist, zato je do smrti živel v upanju, da je mogoče svet popraviti in ga izboljšati. Iz njegovih del veje vera $v$ moč razuma in človeške dobrote.

Izredno veliko časa in energije je posvetil izobraževanju, saj je bil prepričan, da je z znanjem moč popraviti krivice sveta in ga izboljšati. Po njegovem mnenju so ljudje, ki so izobraženi, neprimerno bolj pripravljeni iskati kompromise in se pogovarjati, ne pa se samo vojskovati. Za Komenskega je neznanje največje zlo, ker prinaša bedo in nesrečo med ljudi, vendar pa samo čisto intelektualno izobraževanje in kot posledica tega znanje ni dovolj, potrebna je tudi moralna vzgoja, ki naredi ljudi dobre in usmiljene. Za Komenskega je bilo zelo pomembno hkratno razvijanje in krepitev intelekta in duše, zato se ni popolnoma ujel s svojim sodobnikom R. Descartesom. Prišlo je celo do srečanja med njima (1642), vendar pa je to samo še poglobilo njuno nestrinjanje in odpor, kajti razlikovala sta se že v principih. Komenski je zagovarjal povezanost med vero in znanostjo, medtem ko je Descartes kategorično zavračal mešanje Svetega pisma v znanost. Descartes je eksaktno zaznaval posamezne naravne pojave, medtem ko je bil Komenski goreč zagovornik celovitosti narave in zgodovinske dinamike. Komenski je bil tip humanističnega unitarista, medtem ko je bil Descartes tipični naravoslovni analitik.

Temeljno vodilo Komenskega je bilo, da je treba izobraževati najširše množice ljudi, ne glede na stan, starost ali spol. Z dušo in telesom je bil za razvoj množičnega izobraževanja, lahko bi tudi rekli, da je bil njegov oče oz. začetnik, saj je temelje razložil v delu Typhographeum vivum (Živa tiskarna): šolo in $s$ tem učitelja primerja s tiskarno in tiskarjem, ki naj vednost in znanje vtiskuje $v$ duše učencev, tako kot tiskarski stroj tiska knjige. Ker gre pri tem za veliko izdelkov - učencev, so

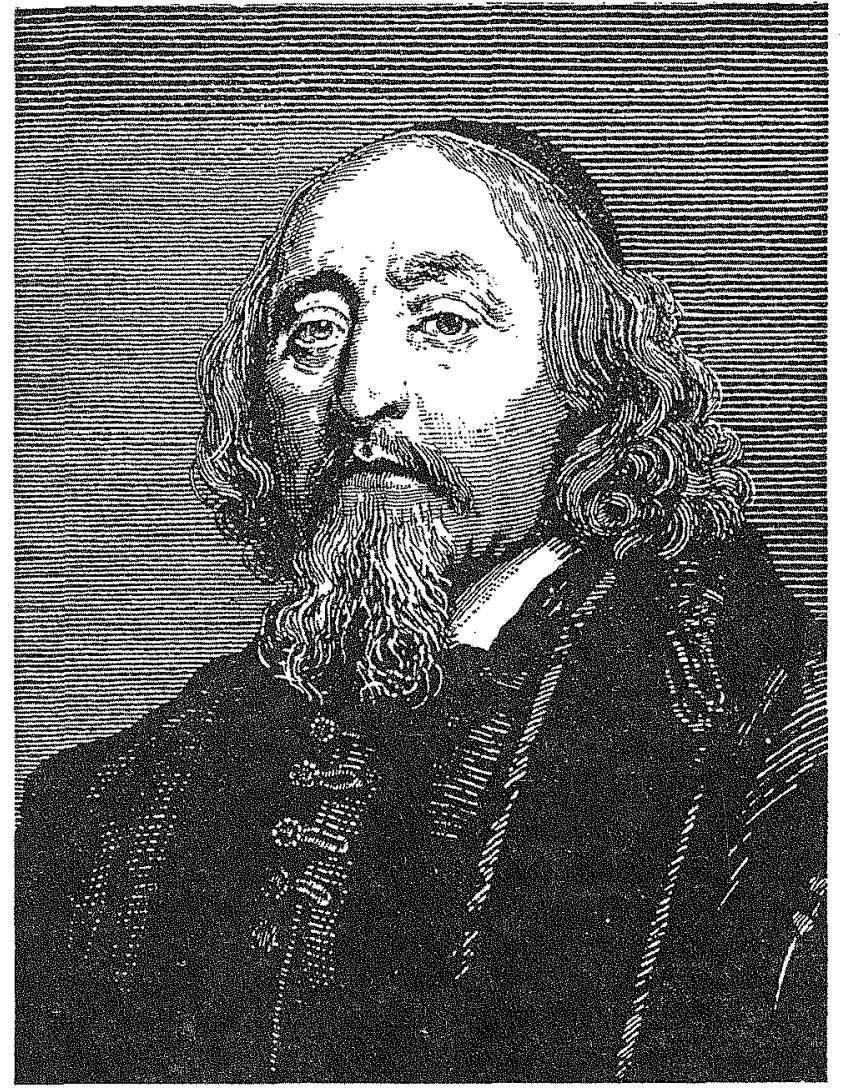

Maks Švabinski, portret J. A. Komenskega

potrebna tudi posebna sredstva, metode in tehnike, ki omogočajo tak način dela. Učenec mora razumeti, kaj se uči, postopoma mora prehajati od lažjega k težjemu, od konkretnega $\mathrm{k}$ abstraktnemu. $V$ čimvečji meri si mora znanje in gledanje na svet pridobiti s pomocjo čutnega zaznavanja in spoznavanja, praktične navade si mora pridobiti z lastnim ravnanjem, nato pa se mora biti s pridobljenim znanjem sposoben dokopati do višje izobrazbe (če obstaja seveda interes - na tega pa apelira Komenski v delu Pampaedia). Po njegovem mnenju je predvsem potrebno, da učenec razume, kaj se uči (v tedanjih šolah s sholastično dediščino so se najprej učili besed $v$ latinščini in šele nato so se poučili tudi o njihovih pomenih, pa tudi to predvsem v obliki suhih, papirnatih defini- 
cij). Komenski priporoča spoznavanje besed hkrati z njihovimi pomeni, in to $v$ materinščini in v latinščini. Uvaja učbenike $\mathrm{z}$ bogatim slikovnim gradivom in bolj življenjskimi temami. Zanimivo je, da so vrednost njegovih didaktičnih spisov prvi spoznali njegovi hudi ideološki nasprotniki jezuiti in so. še za časa njegovega življenja (1667) izdali jezikovni učbenik lanua linguarum reserata (Odprta vrata jezikov) za učence svojih šl, ki so tedaj veljale za najboljše v katoliškem svetu.

Jan Amos Komenski je umrl v Amsterdamu leta 1670.

V zborniku z naslovom De rerum humanarum emendatione consultatio catholica (Splošni posvet o izboljšanju človeških reči), ki je zaradi avtorjeve smrti ostal nedokončan in so ga odkrili šele v 20. stoletju (prvič je bil izdan leta 1935, editio princeps pa šele leta 1966), Komenski izdela program svojega videnja sveta in njegove ureditve. Osrednja temelja (spisa) tega zbornika sta Pansophia (Vsesplošna modrost), utemeljitev razvoja znanosti, in Pampaedia (Vsesplošno izobraževanje), v kateri podaja svoje poglede na izobraževanje kot kontinuiran ciklus, ki mora potekati od rojstva do smrti. Ves čas poudarja prostovoljnost izobraževanja, kar je tudi eden temeljnih postulatov sodobne teorije permanentnega izobraževanja. Večkrat poudari, da je celo človekovo življenje šola, razdeljena na več delov, ki se ujemajo z življenjskimi dobami. Vsaka izmed njih ima poseben program, zahteve in cilje. Prav tako ima tudi vsaka šola več razredov, ki jih Komenski natančno elaborira. V skladu s svojo panzofično teorijo, kjer je svet razdelil na osem specifičnih svetov, razdeli tudi človeško življenje na osem dob - šl, ki naj bi jih človek absolviral.

\section{Opredelinev pampedije}

Za Komenskega je pampedija neke vrste univerzalna kultura (cultura universalis), h kateri spadajo tudi prenos znanja in načinov vedenja, vzgoja in izobraževanje vsega človeškega rodu. Grško pomeni paideia poučevanje (institutio) in nauk (disciplina), po katerem so ljudje poučevani. Pan pomeni univerzalnost, splošnost (universalitas), zato so poučevani pantes, panta, pantos (vsi, vse, scela ali popolnoma).

$\checkmark$ razvoju civilizacije razlikuje Komenski tri stopnje, $k i$ jih poimenuje z:

1. Nič (nihil), kar pomeni, da ni nikakršne kulture; to stopnjo je najti pri »vedno barbarskih narodih, ki jih gledamo $z$ grozo in pomilovanjem, kjer se bedni smrtniki rodijo kot živali, tako živijo in umrejo

2. Nekaj (aliquid) pomeni, da v solah poučujejo nekaj tega, nekaj tistega in nekaj onega. $\gg$ To je najti pri že bolj civiliziranih narodih, ki delijo med seboj znanost, umetnost, jezike in druge študije«. Na tej stopnji je bila po mnenju Komenskega večina evropskih narodov.

3. Vse (omnia), ki pomeni splošno, občo kulturo (cultura universalis), s katero je mogoče "pridobivati božansko podobo človeka, ki je zadnji blesk pred nebesi«. Ta se doseže z realizacijo pampedičnih in panzofičnih naukov.

Z upoštevanjem pampedije je mogoče »oblikovati polno človečnost (humanitas) mnogih, ne samo enega ali redkih; vseh in posameznih ljudi, mladih in starih, bogatih in revnih, plemenitih in neplemenitih, moskih in žensk, na kratko vseh ljudi, ki so se rodilik. Naposled bo tako ves človeški rod dobil možnost za izobraževanje, ne glede na starost, stan, spol ali narodnost.

Človeka je treba izobraževati (pri tem misli tako na vzgojo kot na izobraževanje - T. V.) scela (popolnoma), ne za prazno slavo, ampak za resnico. Treba ga je približati idealu

božje podobe (po kateri je bil rojen).»Mora biti razumen in moder, aktiven in živahen, dobrih navad in pošten, pobožen in svet, srečen in blažen zdaj in na vekomaj.« Komenski je že takrat začutil in izrazil potrebo po razvijanju (vzgoji in izobraževanju - T. V.) človeka v Človeka njegovega skladnega telesnega in duhovnega razvoja, kar je ena temeljnih zahtev permanentnega izobraževanja.

Pravi, da je potrebno »biti moder za večnost, in ne biti neumen za tukaj«.

Vsak človek se mora popolnoma (scela) naučiti, mora znati in biti zmožen povsod trdno stati in varno hoditi, sledeč jeklenemu pravilu Boga in same narave.

Cilj mu je, da bi vsi ljudje postali panzofi, to je:

- da bi razumeli členitev in povezavo stvari, misli in pogovorov;

- da bi razumeli meje (fines), sredstva, poti (media) dejanj in načine delovanja (modos agendi);

- da bi znali razlikovati bistveno od nebistvenega, nezainteresiranost od skodovanja in opaziti lastne in tuje digresije misli, besed in dejanj ter jih vrniti na pravo pot, kajti, kot pravi: »Potem bi svet postal poln reda, luči in miru.«

Še ena definicija pampedije, ki jo je razvil Komenski: je umetnost presajanja modrosti v vse misli, jezike, v vsa srca in $\mathrm{v}$ vse roke.

\section{Vsi lijudje morajo bi̊ni izobrazevani zal alovečnos:}

Komenski želi, da nihče ne bi živel kot divjak, ampak tako, kot zahteva razum, čigar luč nam je bila vsem podarjena, vendar je ne znamo uporabljati, če se tega ne naucimo. Poučevanje (izobraževanje) je zanj bistveno, saj bi bilo $\mathrm{v}$ nasprotnem primeru (če se ne bi učili - T. V.) tako, kot bi imeli polje, pa ga ne bi obdelovali, orgle, na katere ne bi igrali, oči, s katerimi ne bi opazovali, ušesa, s katerimi ne bi poslušali, in noge, s katerimi ne bi hodili. „Čmu nam bo torej razumska narava (rationalis natura), č je ne gojimo za rabo razuma? ¿ Zemljo lahko obdelujemo ali pa zanemarjamo, $v$ obeh primerih je to prehodno, samo za tostransko življenje, medtem ko je c̆loveška duša temelj večnosti, ki ga ni mogoče zanemarjati brez večje škode.

Ena izmed njegovih revolucionarnih trditev zadeva pravico telesno ali umsko prizadetih ljudi do izobraževanja. Pravi: "Postavlja se vprašanje, ali naj tudi slepi, gluhi, omejeni prejmejo vzgojo in izobraževanje.« Na to odgovarja:

1. Iz človeške kulture se ne sme izzvzeti in izlociti ničsar, razen nečloveka. Zato mora biti vsakdo, ki je deležen človeške narave, enako deležen tudi človeške kulture;

2. Povsod, kjer je narava na neki način omejena, skuša to kompenzirati kje drugje. »Primeri kažejo, da so mnogi, ki so se rodili slepi, podprti zgolj s sluhom, postali izvrstni glasbeniki, pravniki, govorniki. Tako kot so gluhi lahko odlični slikarji, kiparji, kovači. Tudi kdor ima pohabljene roke, more biti izboren pisar.«

\section{Sredstww in dejavniki, ki pripomorejo, da iz ălovešlke marave nastane clovelr}

Cilj pampedije je »enciklopedično izobraziti vse, ne pa samo nekaterih. Ne bomo jih opremili samo s tem, kar morejo znati, ampak $\mathrm{z}$ vsem, kar je treba početi in s pregovorom pojasniti. Clovek se razlikuje od živali po razumu (ratio), govoru (oratio) in delovanju (operatio)."

$\mathrm{V}$ vsakem človeku naravni dražljaji (stimuli naturae) povzročajo, da si želi:

biti (to je živeti); krepko biti (to je biti zdrav); zaznavno biti (to je vedeti, kaj ima okrog sebe); jasno biti (to je razumeti, 
kar zna); svobodno biti (to je razumljene stvari, ki so dobre, hoteti in izbrati); aktivno biti (stvari, ki jih razumeva in izbira, mora tudi načrtovati, da ne bi zaman delovali); imeti ali posedovati mnoge stvari; znati varno uživati v vsem, kar ima; izstopati in biti v časteh; biti kar se da vešč govorjenja; uživati naklonjenost in hvaležnost ljudi; biti v milosti pri Bogu.

$\mathrm{V}$ vseh naštetih stvareh si po mnenju Komenskega želi biti izobražena človeška narava.

Zelo pomembno je, da ljudje pridemo do spoznanja mnogih stvari, ni dovolj, da spoznamo stvari samo površinsko, ampak moramo priti do njihovega globljega spoznanja. Ce tega ne storimo, pride do napak pri tolmačenju, pride do praznoverja. Do spoznanja notranjega ustroja stvari pridemo predvsem s pomočjo panzofije, medtem ko nam pampedija skuša to znanje nakapati v dušo.

Komenski upa, da bodo ljudje posedovali mnoge stvari (vsak po svoji potrebi), zato je potrebno vse poučiti o umetnosti bogatenja. Vsakdo naj se nauči imeti dovolj, ne živeti v pomanjkanju in ne hlepeti po tujem.

Upa, da ne bo noben človek mutast, da ne bi mogel in znal razložiti svoje potrebe in stiske Bogu in dobrim ljudem. Vse te ljudi je treba naučiti lepega vedenja: tistih, ki imajo že po naravi lepe lastnosti, ne smemo pokvariti, tiste s slabimi pa je treba popraviti. Najpomembneje pa se Komenskemu zdi napolniti duše vseh ljudi s pobožnostjo, in to pred vsem, med vsem in po vsem. Spet se pokaže pomembnost razvoja človeka kot moralnega bitja.

$V$ nadaljevanju pojasniti namen pampedije in s tem človeka kot celote: »Kdor lahko poreče: naj se kovači ukvarjajo s kovaštvom in vsakdo s tem, kar zna; mar je za to (če bo vsak delal kaj drugega, po svojih zmožnostih - T. V.) potrebno in nujno, da se vsi učijo vsega? Odgovarjam: Narava, ki je roditelj stvari, vsakemu bodočemu človeku v materinem telesu oblikuje iste organe: noge, roke, oči, jezik, vse, četudi ne bodo vsi tekači, pisarji, govorniki. Ker pa so vse to človeške dejavnosti in poklici, oblikuje celega človeka, da bi imel hkrati in naenkrat vse, kar bi mogel potrebovati.«

\section{Treba je izobraževati scela, popolnoma}

Zahtevo, da se morajo izobraževati vsi, v vsem in scela (popolnoma), utemelji Komenski z uvedbo treh dejavnikov (o katerih razvije pravo znanost - T. V.), ki so bistveni za uresničenje pampedije:

1. Za uresničenje ideje o izobraževanju vseh ljudi so odgovorne izobraževalne, vzgojne, kulturne delavnice (officinae culturae), ki jih imenuje univerzalne šole; dejavnik in nauk se imenujeta panscholia (vsepovsod morajo biti šle).

2. Za uresničenje ideje o znanju vsega so potrebna univerzalna sredstva: knjige, ki vsebujejo vse; dejavnik in nauk se imenujeta pambiblia (vsepovsod morajo biti knjige).

3. Za uresničenje ideje o popolnem, celotnem znanju so potrebni univerzalni učitelji, učenjaki, ki znajo prilagoditi vsem vse v vseh pogledih (omnibus omnia omnimode); dejavnik in nauk se imenujeta pandidascalia (vsepovsod morajo biti primerni učitelji).

O svetu brez pampedije pravi: $\gg$ Svet se je valjal v blatu in umazaniji, ker ti trije dejavniki niso bili pravilno urejeni. Ponekod sploh ni bilo šol, torej nobene vzgoje, čisto kmetavzarstvo in barbarstvo. Ponekod so šle bile, vendar niso bile dobre, torej nepravilna vzgoja, bolj pripravna, da pokari človeško naravo, kot da jo izboljša. Zelo redke so bile dovolj dobre, pobožne, svete (šle - T. V.), vendar niso bile dovolj dobro urejene, pravi mlin in labirint. Zato jih je treba ustanoviti vsepovsod, da bodo služile celotnemu človeškemu rodu«.
»Podobno je s knjigami, ki jih nekateri narodi sploh nimajo, drugi pa jih imajo preveč. Veliko jih je polnih raznih napak (filozofskih, medicinskih, političnih, verskih) ali pa, če že vsebujejo resnico, to podajajo na napačen način. Zato je treba tako izboljšati to orodje človeške vzgoje in kulture (humanae culturae instrumentum), da bi jih bilo povsod najti, da jih nikjer ne bi bilo preveč $\ll$.

»Prav tako bo s pedagogi, ki bodo povsod, da bodo samo dobri in učeni in bodo znali poučevati.« Ti pedagogi, kot jih imenuje Komenski, morajo sami razumeti vse, kar človeka dela C̆loveka, ga humanizira, hkrati pa znajo tudi druge ljudi, učence opremiti $z$ vso to vednostjo.

\section{Kaj je to Panscholia, cemu je numenjena}

»Vsaka doba starosti je namenjena učenju in vsem ljudem so dani isti cilji za življenje in za učenje. Človeškega življenja niti smrt niti svet ne končata, saj mora vsak rojen človek iti prek teh meja na nebeško akademijo. Vse pa, kar je prej, je samo pot, priprava, delavnica, je samo nižja šola.« Ta nižja šola traja in mora trajati vse življenje, ker je samo življenje tudi šola«.

Vsaka življenjska doba je primerna za učenje nečesa drugega in če zamudimo pravi trenutek, lahko nastane velika škoda: »Za kar je bila primerna prva doba, ne bo druga, še manj pa bo za tisto primerna tretja. Primer: Deček se katerega koli jezika nauči lahko, mladostnik ali mladenič že težje, medtem ko tisti, ki je postal moskki, najtežje in nikoli popolnoma.«

Nato prostorsko umesti sedem stopenj sol, ki jih posamično opiše v nadaljevanju. »Prve šole (šole rojstva) bodo povsod, kjer koli se rojevajo ljudje; druge (detinske šole) bodo v vsaki hiši; tretje (deške šole) morajo biti v vsaki vasi; četrte (mladostniške šole) v vsakem mestu; pete (mladinske šole) v vsakem kraljestvu ali v večji pokrajini; šeste (moške šole) povsod po svetu; sedme (šle za starce) pa vsepovsod, kjer je najti ljudi, ki dolgo živijo«. Za prvi dve šoli pravi, da sta zasebni (private), ker so zanju odgovorni starši doma; naslednje tri so javne (publicae) in jih javno nadzorujeta Cerkev in civilna oblast; zadnji dve sta pa osebni (personales), saj mora vsakdo biti svoj učitelj in učenec.

Zahteva sicer, da se izobražujejo vsi, ne glede na spol, vendar se morajo izobraževati deklice ločeno od dečkov, zaradi spodobnosti. $V$ javnih šolah naj se učijo:

- pismenosti, znanosti in umetnosti,

- lepega vedenja,

- pobožnosti.

Razlogi, ki jih navaja za argumentiranje množičnega (javnega) izobraževanja, so: v mladino je mogoče vliti več znanja, ji vsaditi boljše navade in izkoreniniti - sčasoma - več napak, večji je prihranek truda in stroškov, ko najboljši učitelj ni najet, da bi z znanjem napolnil samo posamezne učence, ampak vse hkrati.

Komenski sicer ugotavlja, da so že prej obstajale javne šole, vendar od njih ni bilo kakšne posebne koristi. Razlogi so naslednji:

- Šole sprejemajo že s prvotno vzgojo pokvarjene učence in imajo zato dvojno delo in dvojni trud: najprej jih morajo odvaditi vsega slabega, šele nato jih lahko naredijo boljše.

- Učenci so v šolah samo določen čas, nekaj ur, zato potem, ko se vrnejo domov, spet zapadejo pod slabe vplive.

- Posebej pa so v obstoječih šlah neznani načini napeljevanja duha učencev $\mathrm{k}$ dobremu; večina učiteljev namreč s svojo čemernostjo in naklonjenostjo sibi ali pa z grobostjo pri pouku naravnost odbija učence od sebe in od sole.

Odgovora na to, ali naj se plemiči šolajo skupaj s podložni- 
ki in meščani, ne podaja eksplicitno, vendar se da iz zapletenega besedila razbrati, da zagovarja takšno možnost in jo priporoča (za tiste case je bilo to prav nezaslišano $-\mathrm{T}$. V.)

Šole morajo stati na takih krajih, da bodo lahko dostopne vsem učencem (ali v središču mesta ali pri cerkvi). Začetek in konec pouka $\mathrm{v}$ šoli in posameznih razredih naj se ujema $\mathrm{z}$ začetkom in koncem koledarskega leta.

$\mathrm{V}$ šoli je treba uporabljati praktične in prijetne metode poučevanja, takšne, da more šola postati zabava, natančneje prijeten uvod $v$ »pravo «življenje. Ko učenci zapustijo šolo in se srečajo $z$ raznimi opravili življenja, se jim ne sme nič zdeti novo, ampak jim mora biti vse samo nova in prijetna, resnemu delu namenjena izpeljava že znanega.

\section{Kai je to Pambiblia, cemu je numenjena}

»Pambiblia so knjige, namenjene univerzalni vzgoji, pravilno pripravljene po zakonih univerzalne metode.«

Knjige, ki se uporabljajo v pampediji, morajo biti napisane:

- neposredno;

- polno in

- jasno.

Navaja tudi podrobnejša navodila za pisanje šlskih knjig učbenikov. Piscem priporoča, naj pišejo knjige v obliki dialoga in po matematični metodi, kar pomeni čim manj razpravljanja in čim več demonstriranja. Komenskemu se zdi zelo pomembno, da so knjige napisane tako, da morejo služiti tudi samoučenju (autodidactus) zunaj šole.

\section{Kai je to Pandidascalia in remu je namenjena}

Splošni učitelj (pandidascalus) je »pampedični učenjak, ki zna poucevati (informare) vse ljudi o vsem, kar dovršuje človeško naravo, da bi naredil ljudi popolnoma, scela dovršene «.

Nato natančno opredeli lik pampedičnega učitelja: kaj mora znati, kakšne kreposti in značajske lastnosti se zahtevajo od njega.

V nadaljevanju Komenski podrobno govori o osmih šolah, ki trajajo vse življenje, jih opiše ter jim določi cilje, sredstva in metode dela. $V$ teh poglavjih je enkratno predstavljeno permanentno izobraževanje $z$ vsemi zahtevami, ki v veliki meri (ponekod povsem) ustrezajo merilom današnjega časa.

Šola rojstva (schola geniturae) ali koristen pouk o prvi skrbi za človeški rod, še v materinem telesu.

V tem poglavju razpravlja Komenski o skrbi za otroka, še preden se ta rodi. Daje nasvete zakoncem o zakonu, spočetju in zdravi nosečnosti. Ta šola traja od otrokovega rojstva.

Detinska šola (scholla infantinae), materino naročje ali o skrbi za oblikovanje potomstva od rojstva do šestega leta starosti.

Postavi definicijo, da je dete (infans) mlad človek, ki je šele vstopil v ta svet in je še v vseh rečeh neobdelan (rudis), neizobražen in ga je treba vsega naučiti;

Ta šola ima šest razredov:

1. razred poroda (classis puerperii), traja poldrugi mesec;

2. razred dojenja (cl. lactationis), traja poldrugo leto;

3. razred uspavank in hoje (cl. lallationis et incessus);

4. razred govorjenja in oblikovanja pojmov ( $\mathrm{cl}$. fantilitatis et sensuationis);

5. razred vedenja in pobožnosti ( $\mathrm{cl}$. morum et pietatis);

6. prva soseška šola ali šola prve pismenosti (schola conventualis prima sive schola literaturae primae).
Deška šola (schola puerilis) ali o modrem in preudarnem oblikovanju mladine od šestega do dvanajstega leta starosti.

Postavlja definicijo, da so dečki (pueri) mladi ljudje, bodoči nasledniki tistih, ki tvorijo in vodijo zdajšnji svet (Politiko, Cerkev, Šolo).

Ta šola ima šest razredov, ki imajo imena po šestih knjigah, ki se uporabljajo v njih:

1. Novinec v pismenosti (Tirocinium literarium);

2. Zaznavni svet (Orbis sensualium);

3. Deška etika (Ethica puerilis);

4. Izvleček iz biblijskih zgodb (Historiarum Biblicarum epitome);

5. Jedro Biblije (Medulla Biblica);

6. Deška sfinga (Sphinx puerilis).

Mladostniška šola (schola adolescentiae), (borišče) jezikov in umetnosti, predvsem latinskih, pa tudi drugih učenih znanosti in umetnosti, enciklopedija nravi in pobožnosti.

Postavlja definicijo, da so mladostniki (adolescentes) mladi ljudje, ki so končali deško dobo, še zmeraj pa so postavljeni pod norme postave, sodb in moči.

Ta šla ima šest razredov, ki jih utemeljuje tudi Velika didaktika:

1. Slovnica (Grammatica);

2. Fizika (Physica);

3. Matematika (Mathematica);

4. Etika (Ethica);

5. Dialektika (Dialectica);

6. Retorika (Rhetorica).

Mladinska šola (schola iuventuits), akademija, namenjena za pridobivanje polnejš modrosti.

Postavlja definicijo, da je mladenič (iuvenis) tisti, ki je za sabo pustil mladostništvo in dosegel (predvideno - T. V.) telesno postavo, utrjuje pa še telesne in duševne moči.

Ta šla ima tri dele:

I. Akademijo (Academia) s tremi razredi:

1. Panzofični r. (Pansophica);

2. Pambiblični r. (Pambiblica);

3. Panetoimični (vsesplošno učeni), ali preizkusni r. (tudi v Veliki didaktiki, Panetoimica, Panepistemonica, Examinatoria).

II. Apodemijo (Apodemia; popotovanja v tuje kraje).

III. Izbor življenja (Delectus vitae).

Naslednji dve poglavji, ki opisujeta moško šolo in šolo za starce, bi si, zaradi andragoškega interesa za koncepcijo izobraževanja odraslih J.A. Komenskega, ogledali malce podrobneje.

Moška šola (schola virilitatis), umetnost dobrega življenja in uspešnega upravljanja svojih stvari ali praksa življenja.

Postavlja definicijo, da je moški (vir) človek, ki je dosegel mejo (pričakovanega razvoja - T.V.) telesne postave in moči in je sposoben za različna opravila in dejansko že začenja živeti tako, kot se je pripravil.

Za Komenskega je vse življenje šla in je odraslost (moškost) osrednji del, ki je zanj en sam razcvet, celo največji razcvet, kajti vse prejšnje dobe in šole (detinska, deška, ...) so imele cilj priti le do sem. Potrebo in nujo po izobraževanju odraslih utemelji, ko zapiše: »Kjer se ne bi napredovalo (po izstopu iz ciklusa formalnega izobraževanja - T.V.), bi se nazadovalo, še posebej, ker se je še mnogo vsega treba naučiti, in to ne več v igri, ampak $z$ resnim delovanjem. Tistega, ki je 
učljiv, morejo veliko stvari naučiti že iz nižje šole, ki jih je že prehodil, nobena pa več od te, v katero vstopa, saj pomeni resno obravnavo stvari samih in stike $\mathrm{z}$ različnimi ljudmi $\mathrm{v}$ teku celega življenja.«

Sledi utemeljevanje potrebe po moški šoli, po nadaljevanju izobraževanja, ki je, kot bomo videli v nadaljevanju, predvsem avtodidaktično: $\gg$ Niti najmanj se ni zlagal tisti, ki je rekel: ,Mnogo sem se naučil od svojih učiteljev, več od sošolcev, največ pa od učencev' kajti s tem, ko gradimo, smo tudi sami grajeni (fabricando fabricamur) in $\mathrm{z}$ delovanjem postanemo tudi sami strokovnjaki za različna opravila... Prava sholastična metoda prav tako teše s tesanjem, namreč $z$ neprestano izpeljavo teorije v prakso izurja za opravljanje nalog, ker pa se praksa uporablja $v$ šoli samo zaradi vaje in urjenja in se obravnava nekako igraje, ima podobo igre in ne more pokazati tako resničnega in resnega napredka, kot ce bi bila izvajana z vso resnostjo in primerno letom za resne reči. Moška šola vsebuje umetnost dobrega življenja in uspešnega delovanja ali prakso življenja... Teoretik brez prakse je kot mornar iz knjige, ki varno sedeč na klopi izvrstno opisuje pristanišča, čeri, rtiče, Scile in Karibde, medtem ko ladjo odlično vodi po kuhinji ali pa mizi. Če pa tak mornar pride na morje in $\mathrm{mu}$ zaupaš krmilo troveslače, bo takoj trčil v tiste čeri, ki jih je prej tako dobro poznal.« Nato povabi mladeniče, ki so končali šole, naj se naučijo biti mornarji na morju življenja in naj se ucijo opravil, ki jih tukaj čakajo. V moški šoli se bodo pripravljali na odgovornost do sebe in do drugih, kar ponazori z lepo primero: $\gg$ Brezzobim dečkom dajemo mleko, tistim pa, ki že imajo zobe, dajemo mehko hrano: zrelejši jedo sami, odrasli pa sami pripravljajo hrano sebi in svojim. Tako se vašim dojenčkom, otrokom in mladini daje že pripravljeno, vam, zrelim, ki že imate zrelo modrost, pa je, $z$ vašo lastno iznajdljivostjo zaupana vloga pri pridobivanju dobrin vam in vašim. Vi ste že sami sebi bodoči učitelji in učenci.«

$\checkmark$ utemljevanju potrebe po nadaljevanju izobraževanja, seveda neformalnega, spregovori Komenski tudi o življenjskih ciljih in pravi, da je cilj življenja zagotoviti, poskrbeti za modro upravljanje, da ne bi bilo kaj od tega, kar smo si v mlajših letih pridobili, izgubljeno (izobrazba - eruditio, navade, vedenje - mores, pobožnost - pietas). Vse mora biti pravilno izrabljeno, torej je treba učiti ljudi, kako naj uporabijo luč modrosti, ki so jo nabrali, za delovanje v življenju, da bi potem mogli brez težav iti skozi dobro in zlo in da bi kar najbolj končali svoje življenje.

Komenski je utilitarist, zato želi tudi bodoče »učence«navajati na čim boljšo izrabo casa in postavlja v ospredje vidik koristnosti pridobljenega znanja. Kot primer (exemplum) navaja Plinija, o katerem pravi, da ni ničesar prebral, ne da bi prej preveril, ali je vredno branja (nihil legit, quod non seligeret). »Ti pa, ko si postal mož, glej, da se bo lahko reklo: Ničesar ni prebral, rekel, storil, česar ne bi mogel uporabiti koristno življenje.«

Kot vsako izmed sol, je tudi moško šolo razdelil na razrede oziroma dobe. $V$ moški šoli so trije razredi:

1. Tisti, ki postajajo moški oz. tisti, ki začenjajo živeti življenje.

2. Tisti, ki nadaljujejo življenje.

3. Tisti, ki vodijo svoje življenje proti koncu.

$V$ vseh razredih moške šole je najbolj uporabljana metoda meditacija, razmišljanje o določenih temah, ko si zastavljamo probleme in jih nato skušamo rešiti.

Komenskemu je življenje samo tudi šola in to celo zelo pomembna šola, ki pa je odvisna od vsakega posameznika. Učno sredstvo $v$ tej šoli so tudi šolske knjige, zato naj tisti, ki so končali s formalnim solanjem, knjig ne zavržejo kakor kakšnih spon, ki so jih vklepale, kot to počne večina (zelo se zgraža nad takim početjem - T.V.), ampak naj jih raje obdržijo in vedno znova berejo. Pri tem navede, kot ima navado, primer iz vsakdanjega življenja: »Mar ne boš rekel, da je neumen tisti delavec, ki brusi sekiro in jo, ko je nabrušena, zavrže (Annon enim desipere dicas mechanicum acuentem securim, exacutam vero abjicientem?)? In kaj je bolj pogubnega, kakor če se hočejo tisti, ki so po mnogih letih naporov popolnoma izčrpani, v celoti odpovedali sadu svojega časa? (odpoveš se namreč, če ne nadaljuješ, kajti ne napredovati, je nazadovati/non progredi hic regredi est). « Vsaka šola temelji na poučevanju primerov (exampla), naukov (praecepta) in na vajah (exercitia), zato se morajo moški zdaj sami ukvarjati z zgodovino, kjer se poučijo o primerih, $v$ dogmatičnih knjigah naj iščejo nauke in modrost, nepretrgoma pa naj se $\mathrm{v}$ vsem tam urijo $\mathrm{v}$ življenjski praksi.

Moška šola je, po znamenju Komenskega, svobodnejša, saj ni toliko povezana $z$ določenimi obveznimi knjigami in učitelji, ker je vsakemu posamezniku njegov poklic že neke vrste šola. Vsakdo je zato svoj učitelj pa tudi svoja knjiga in sola; vsak si mora sam dajati primere in nauke ter skrbeti za nepretrgano urjanje. Ker pa oči vidijo več kakor oko, nihče ne vidi tako dobro, da ga ne bi mogel prijatelj, bodisi živ, bodisi že mrtev, na kakšen način opomniti ali mu svetovati.

Poleg Svetega pisma priporoča tudi branje drugih - dobrih, kot jih sam imenuje - knjig: zgodovinske, filozofske in teološke za razvoj razuma; govornike in pesnike za razvoj stila; moralne in mehanične (strokovne, s področja fizike, kemije, ...) pa tudi zaradi dela, s katerim se človek ukvarja, in razsodnost pri delu. Vse te odlike pa je po njegovem mnenju mogoče najti tudi $v$ delu enega samega pisca, tako kot »na istem travniku išce vol travo, pes zajca, čebela pa cvetove «. Primera za takega pisca oziroma naslova dela ne navaja, cetudi je verjetno, da ima $v$ mislih panzofična dela, o pripravi katerih govori v pambibliji (VI. poglavje Pampaediae). Ker pa še ni take knjige, ki bi bila »dobra« $v$ vseh pogledih, je treba brati veliko knjig. Vseh pa clovek ne more prebrati in tudi ne bi bilo pametno, zato je potreben dober izbor; pri tem moramo posnemati čebele, ki iz cvetov posrkajo med, strup pa pustijo. Problem pa je v tem (ta se mu zastavlja kot učenjaku), da ni knjige, najsi je še tako slaba, ki ne bi vsebovala vsaj nečesa dobrega. Zato moramo ravnati tako, kot bi storil moder in razsoden mož na razkošni pojedini; vse si natančno ogleda, za svojo rabo pa izbere zelo malo, vendar najboljše. Malo, vendar kakovostno. V zvezi z zgodovinskimi knjigami kot učnimi viri Komenski pripominja, da je bolje brati sodobne zgodovine in kronike kakor antično zgodovino, ker je svet in njegov razvoj od začetka do konca šola celotnemu človeškemu razumu. Biča učenjake, ki hočejo vedeti vse, kar se je zgodilo v stari Grčiji in Rimu, prav malo pa jim je mar, kaj se dogaja danes doma. Groza ga je ljudi, ki »jih skrbi za tuje hiše, lastnina pa jim propada v umazanijik.

Nikdar ne smemo vzeti v roke knjige, ne da bi potem, ko jo odložimo, čutili, da je del nas postal razumnejši, pametnejši ali boljši.

Življenje je pot $\mathrm{k}$ starosti, smrti in $\mathrm{v}$ večnost, zato je treba $\mathrm{v}$ tej dobi, v tej šoli opraviti vse za starost. Komenski sam meni, da starost ni popolnoma neplodna, kljub temu pa mora vsakdo v poletju svojega življenja napolniti svoje skednje in kleti z živežem modrosti in $z$ vsem drugim, kar je potrebno, kajti šele potem bo starost prijetna. Pripraviti pa je treba le tisto, kar je nujno za udobno starost, in ni treba pretiravati.

Življenje je napor in trud, zato navaja nekaj pravil, ki bi se jih bilo treba $v$ moški šoli držati:

- Delaj samo tisto, za kar poznaš namen in cilj (le neumneži delajo v prazno).

- Ničesar ne delaj, ne da bi poznal sredstva, s katerimi boš prišel do cilja. 
- Delaj cim bolj preprosto.

- Delaj, kolikor le moreš dobro ali hitro.

- Če se ti res pokaže nepričakovana priložnost, verjemi, da jo je ponudil Bog (in jo izrabi - T.V.).

- Vedi, da preudarni ne planejo kar takoj po ponujeni priložnosti.

- Opiraj se zgolj na Boga in na samega sebe.«

Vsak človek si mora najprej zamisliti cilj življenja in vsakega posameznega dela. Nato si zamisli sredstva, s katerimi ta cilj omeji in natančneje določi. Potem vse pregleda $\mathrm{z} \gg$ očesom previdnosti «, tako da mu naposled, ko je vse pravilno pripravljeno, ostane le še uresničitev želenega.

Življenje je po mnenju Komenskega komedija (zgodba), razdeljena v dejanja - življenjske dobe. Zanj je moder tisti, ki še pred smrtjo uspešno razplete zgodbo življenja, neumen pa tisti, ki se komajda loti resnih stvari ali pa se jih sploh ne loti, medtem ko je preveč zaposlen $\mathrm{z}$ reševanjem čisto postranskih zadev.

$\mathrm{V}$ drugem delu tega poglavja spregovori o nalogah in ciljih posameznih razredov moške šole. Kot smo že videli, ima ta šola tri razrede:

1. tisti, ki se izbirajo in začnejo s pravim življenjem,

2. tisti, ki nadaljujejo tako življenje, in

3. tisti, ki se nagibajo h koncu in pričakujejo starost.

V prvem razredu so cilji življenja naslednji: naše življenje (ki ga imamo možnost sami izbrati) naj bo:

- varno,

- častno,

- koristno in

- prijetno (to je mirno in udobno).

Vsakdo, bodisi govornik, zdravnik, uradnik, podložnik, delavec ali trgovec mora biti pripravljen služiti drugim ljudem in Bogu, ne razume svojega poklica (vocationem) ali pa ga sprevrženo izrablja, vendar s tem še najbolj škoti samemu sebi ... Vsak poklic, četudi je še tako nizek in preprost, more biti pot do nebeškega kraljestva, kajti Bogu ni noben poklic tako majhen ali zaničevanja vreden, da mu ne bi ugajal in da človeku ne bi mogel prinesti zveličanja.«

Komenski navaja naslednja pravila, ki se jih bo treba držati, če hočemo postati in biti modri ter razsodni:

- Zmeraj in povsem moramo misliti na konec, sredstva, način in prakso. Cilj je pri tem treba poznati zaradi njega samega, sredstva pa zaradi cilja.

Živeti moramo vsem na očeh in javno korist, tako da se lahko o nas reče: je dober človek in dela v splošno dobro.

Pri izboru načina življenja je treba paziti tudi na skrb za družino. Zato so najboljši trije poklici: poljedelski, obrtniški in trgovski. Najboljše je seveda poljedelski (najbolj pošten, najmirnejši, brez zvijač). Očetom priporoča, naj se zgledujejo po mravljah, saj ne poznajo brezdelja, in po čebelah, saj ne poznajo zmede in nereda.

Pravila in cilj tistih, ki so vstopili v drugi razred moške šole, so:

- Kakor so bili prej marljivi $\mathrm{v}$ šoli, tako naj bodo zdaj $\mathrm{v}$ cerkvi.

- Skrbijo naj predvsem za to, da bodo njihova srca, duse in telesa božji templji.

- Modri se ne bo tako zelo prepustil praktičnemu življenju, da mu ne bi ostalo časa za razmišljanje (kontemplacijo).

- Narediti je treba vse, kar ukaže Bog, in potrpežljivo, brez pritoževanja prenašati, kar koli nam naloži.

- Ničesar se ne boj tako kakor Boga, ničesar ne ljubi in ne spoštuj tako.

- Začni živeti tako, da se boš zavedal, da boš nekoč umrl. Možje naj živijo tako, da se jim kasneje ne bo treba pritoževa- ti glede starosti, češ da je kot bolezen, ampak da se je bodo veselili kakor prijetnega počitka po naporu. Delati je treba hitro, da je cilj življenja dosežen pred koncem življenja.

- Vsakdo naj se odlikuje po svojem poklicu kot resen.

$V$ tretjem in zadnjem razredu moške šole omenja Komenski kot vrhunec človeške sreče konec hrepenenj in možnost, da duša doseže polno umirjenost. Sredstva za dosego tega cilja so:

- Malo je treba hoteti, tisto pa trdno.

- Treba je pohiteti z dokončanjem že začetega, izrabiti vsako priložnost, nobene izpustiti.

- Zmeraj je treba biti v milosti božji.

Pri vsem pa je treba zmeraj misliti na smrt, kajti, kakor je gotovo, da se rodimo, tako zanesljivo je treba tudi umreti - le tega ne vemo, kdaj.

Na koncu navaja še temelje modrosti moške dobe:

- O neznani stvari ne smemo sploh ničesar sklepati, trditi, ničesar $v$ celoti $v$ zvezi $z$ njo početi.

- O vsaki stvari je treba najprej pri sebi razmisliti in se odločiti, šele potem na glas povedati ali poskusiti kaj narediti.

- Modrost je torej o stvareh vešče (scite) razmišljati (cogitare), govoriti (loqui) in jih početi (agere).

- Polna in trdna modrost je stvari jasno in pošteno premisliti (excogitare), predstaviti (eloqui) in narediti (efficere).

- Vrhunec (dovršitev) razmišljanja je razumeti vsako stvar tako, kot je, dobra ali slaba; izbrati dobro in zavreči slabo; slediti dobremu in ga doseči, bežati pred slabim in mu ubežati. Popolnost duha sestoji iz jasnega razumevanja stvari, dobre volje, vztrajne marljivosti.

Sledijo stvari, za katere bi bilo lepo in koristno, da bi jih upoštevali:

- Treba je biti zaposlen le z nujnimi stvarmi, takimi, ki težijo k cilju.

- Ne loti se ničesar, česar ne moreš narediti z Bogom.

- Kar koli že začneš delati, naj bo koristno, naj ima znana sredstva in lahek način.

- Kjer se ti sam lahko izkažeš, ne pričakuj tega od drugih.

- Kar lahko storiš danes, tega ne prenašaj na jutri (quod hodie fieri potest, in crastinum differe cave).

- Ce se pokaže priložnost, jo izrabi in misli, da je predvsem delo previdnosti.

- Živi tako, kot bi zmeraj nameraval umreti, in umri tako, kot bi zmeraj nameraval živeti.

- Zmeraj išči Boga, in ne sveta.

- Zmeraj moramo delati tisto, za kar bi želeli, da bi bilo narejeno na koncu.

\section{Šla zo sturce (schola senii)}

Vsebuje vrh človeške modrosti o uspešnem dotikanju konca umrljivega življenja in srečnem vstopu v nesmrtno življenje ali uživanja življenja.

Tudi za starost, ki je zadnji in upadajoči del življenja ter soseda smrti, velja, da je šola. Celotno tostransko življenje je nižja šola, v kateri se pripravljamo na akademijo večnosti, in ker je starost del življenja, je tudi del šole, je torej sola in zato je nujno, da ima svoje učitelje in nauke, svoje naloge in študije ter svojo ureditev.

Komenski pravilno ugotavlja, da imajo starci svoje posebne napake in vedenjske odklone, zato je, kot pravi sam, "proti njim treba uporabiti posebna zdravila in metode zdravljenja«. Zahteva posebne metode za delo s starejšimi.

Kot cilj šole starcev navaja Komenski dober konec tostranskega življenja in primerno pripravo na vstop v večno življe- 
nje. $V$ tej šoli je treba poučevati in se učiti, kako naj starci morejo, znajo in hočejo:

- pravilno uživati v tem, kar so naredili,

- pravilno preživeti ostanek življenja,

- umirljivo življenje pravilno končati in veselo vstopiti v večno življenje.

Tudi to šolo tako kot moške razdeli na tri razrede:

1. Tisti, ki prestopajo vrata starosti in si ogledujejo, kaj so že storili in kaj jim še ostaja.

2. Tisti, ki so stopili $\mathrm{v}$ zrelo starost in hitijo dokončati, kar jim je še ostalo.

3. Ostareli, ki čakajo samo še na smrt.

Nauki, ki se jih morajo držati »učenci « prvega razreda:

Starci morajo uživati tisto, kar so kot mladeniči pripravili in kot odrasli naredili. Ne spodobi se jim, da bi šele zdaj začeli živeti. Kljub pravici do uživanja sadov minulega dela pa se ne smejo vdati brezdelju in otopelost, ker je starost del življenja, vse življenje pa je delo in trud; predvsem morajo dokončati dela, ki so že v sklepni fazi. Naučiti se morajo dobro umreti, kar je po Komenskem umetnost vseh umetnosti.

Kot vsaka šola uporablja tudi šola za starce pri svojem delu posebne metode in načine, ki so:

- Primeri: kot primere (exempla) morajo »učenci uporabiti vse, ki so to poslednjo šolo pred nebesi modro dokončali, kolikor se da to razbrati iz zgodovinskih virov, v poštev pa pridejo tudi preminuli sodobniki;

- nauki in opomini: najdemo jih predvsem v božjih knjigah, $\mathrm{v}$ poštev pa pridejo tudi sodobni opominjevalci, ki živijo $\mathrm{z}$ nami ali pa nas nagovarjajo $v$ knjigah ter

- stalna praksa: starci imajo mnogo izkušenj, zato morajo svoje znanje prenesti v prihodnost, na prihodnje rodove. Pri tem navede čudovito primerjavo človeškega življenja $\mathrm{z}$ drevesom: »Tako kot drevo zgodaj spomladi oblikuje cvetove, jih potem, ko je čas za oblikovanje sadov, odvrže in da sadove ljudem, ter dokler je le mogoče, obdrži samo liste (sebi v kras in za varnost), naposled pa še te odvrže in ga samo še korenine priklepajo na zemljo; tako je s človekom, ki po cvetu mladosti in po kakršnih koli že sadovih življenjskih prizadevanj, dokler mu to uspeva, ohranja kras svojih krepkosti, naposled pa se loči tudi od tega in se pridruži svojemu Bogu, korenini večnosti.«

$\mathrm{V}$ drugem razredu je najpomembneje, da starci:

- čisto mislijo (priznajo in popravijo napake življenja),

- čisto govorijo ( $\mathrm{z}$ dobrimi nasveti pomagajo drugim) in

- čisto delajo (samo tisto, kar se spodobi kandidatom za nesmrtnost). Sramota je gobezdavi starec brez dejanj.

Naloga starcev tega razreda je tudi, da napišejo oporoko, katere cilj je priporočiti dušo Bogu, telo zemlji, premoženje dedičem in spomin nase vsem.

$V$ tretjem razredu se morajo starci samo še cim bolje pripraviti na bližnjo smrt in na večno življenje.

\section{Šla smrti (schola mortis)}

Na koncu Komenski doda samo še šlo smrti, ceprav tudi sam pravi, da jo je podrobneje opisal in definiral že v šoli za starce. O njej govori, ker »zadeva vse življenjske dobe, in ne le starosti, in ker je nekaj drugega dolgo, prijetno umiranje kakor starost

Tako kot je njegovi panzofiji dodan osmi svet, je dodana tudi osma šla, da lahko izpelje paralelizem po dveh in dve parih: prvi in zadnji svet ter prva in zadnja šola itd. $V$ panzofiji je osem svetov: možni (mundus possibilis), arhetipni ( $m$. archetypus), angelski ( $m$. angelicus), naravni ( $m$. naturalis), umetni (m. artificialis), moralni (m. moralis), duhovni (m. spi. ritualis) in večni ( $m$. aeternus), ki jim ustreza osem šol: šola rojstva (schola geniturae sive nativitatis), detinska (s. infantiae). deška (s. pueritiae), mladostniška (s. adolescentiae), mladinska (s. iuventutis), moška (s. virilitatis), za starce (s. senii), šola smrti (s. mortis).

Kot nam je po vsem lahko razvidno, moremo Komenskega upravičeno imenovati oče permanentnega izobraževanja (gotovo so tudi drugi pedagoški teoretiki čutili potrebo po kontinuiranem izobraževanju, vendar jo je Komenski prvi elaboriral in jo jasno opredelil s cilji, sredstvi in metodami). Komenski odločno zahteva, najse ciklus izobraževanja ne pretrga po koncu formalnega šolanja, ampak naj se nadaljuje tudi potem, vse do smrti. Izdela tudi natančno shemo oz. program takega neformalnega izobraževanja, ki pa je še zmeraj dovolj fleksibilen za prilagoditev individualnim potrebam.

Pomemben prispevek k moderni teoriji je tudi njegova zahteva po enakomernem in skladnem razvoju celotne osebnosti, tako telesa kot tudi duha. Najpomembnejši cilj,vzgoje in izobraževanja v času celega življenja - od rojstva do smrti - je vsestranski razvoj osebnosti, osebnost razvijamo predvsem zaradi nje same, da bo človek bolj human in boljši, ne samo zato, da bo potujoča enciklopedija. $V$ tem je tudi veličina pedagoške misli Komenskega. Menim, da je J.A. Komenski (s tem pa tudi njegovo pedagoško in filozofsko delo) še vse premalo znan in navzoč v naši zavesti, saj bi lahko marsikateri biser iz njegove teorije še danes plemenitil našo vzgojno in izobraževalno prakso.

Vidmar, Tadej

Asistent za zgodovino šolstva na Filozofski fakulteti v Ljubljani

\section{Liferafura}

Comenius, I. A.: Pampaedia, v: De rerum humanarum emendatione consultatio catholica, tomus II., pars IV., Academica scientarium Bohemoslovaca, Pragae MCMLXVI (1966).

Medveš, Z.: Interpretacije nazorov Jana Amosa Komenskega pri Slovencih, v: Sodobna pedagogika, 3-4, 1992, str. 118-134.

Panek, J.: Jan Amos Komenski-Ceški humanist na poti k boljšanju reči človeških, Educa, Nova Gorica, 1993.

Savičvič, D.: Obrazovanje odraslih u delu J. A. Komenskog, V: Pedagogija 1, 1970, str. 129-139. 